\title{
DAMPAK TRANSFER FISKAL DAN BELANJA MODAL PEMERINTAH DAERAH TERHADAP PEREKONOMIAN SEKTORAL, KETIMPANGAN DAN KEMISKINAN DI INDONESIA
}

(Impacts Transfer Fund and Regional Governments Spending for Capital on Economic Growth, Inequality and Poverty in Indonesia)

\author{
Nor Qomariyah $^{1}$, Suharno ${ }^{2}$, D.S. Priyarsono ${ }^{2}$ \\ 12 Fakultas Ekonomi dan Manajemen, Institut Pertanian Bogor
}

\begin{abstract}
National economic development goal is to improve the welfare of society and to create equitable distribution of income (Todaro and Smith, 2006). In other words, the success of economic development is indicated by the reduction of poverty and income inequality. Poverty is fundamental problem in the economic development of Indonesia and other developing countries in general. The main objectives of this study are to evaluate impacts of Infrastructural budgetary allocation on GDRP sectoral, inequality, and poverty in Indonesian provinces both in the areas where the contribution of the agricultural sector to GDRP is either high or low, in the era of fiscal decentralization. The dynamic simultaneous equation models were used in this study. It used pooled data of 2009-2013 and cross section data of 19 provinces where classified into two groups, based on the contribution of agriculture sector to the respective regional economy. The methode for parameter estimation used in this study was 2SLS. The result of the study showed that the budgetary allocation for infrastructure and agriculture increase the employment and the GRDP sectoral, decrease income inequality, and then reduce poverty both in the areas where the contribution of the agricultural sector to GRDP is either high or low. This study recomended that the central government should improve the injection of funds directly to the regions through a special allocation fund for infrastructure and agriculture as an effective impact on reducing poverty.
\end{abstract}

Keywords: Economic growth, Inequalty, Infrastructure, Poverty, Specific allocation fund

\section{PENDAHULULUAN}

Pembangunan ekonomi bertujuan untuk meningkatkan kesejahteraan masyarakat serta menciptakan distribusi pendapatan yang merata (Todaro dan Smith, 2006). Keberhasilan pemerintahan dalam mencapai tujuan pembangunan seringkali dinilai dari perubahan tingkat kemiskinan.. Kemiskinan merupakan permasalahan mendasar dalam pembangunan. Tingginya tingkat kemiskinan akan berdampak sangat buruk terhadap perekonomian dan pembangunan nasional, yaitu berupa instabilitas sosial, ketidakpastian, dan tragedi kemanusiaan seperti kelaparan, tingkat kesehatan yang rendah dan gizi buruk. Bila keadaan tersebut terus berlanjut, maka pada akhirnya akan mengganggu keamanan, stabilitas ekonomi makro dan kelangsungan pemerintahan yang ada (Muslianti, 2011).

Berdasarkan beberapa studi sebelumnya untuk mengurangi kemiskinan dicapai dengan meningkatkan pertumbuhan ekonomi. Dimana Arthur Lewis mendefinisikan bahwa faktor yang mempengaruhi 
pertumbuhan adalah tenaga kerja dikaitkan dengan pemanfaatan capital. Senada dengan Lewis, Harrod Domar menjelaskan pertumbuhan ekonomi adalah suatu formula kausalitas antara investasi, tabungan, modal, dan penduduk untuk mempengaruhi hasil/output (Ray, 1998).

Robert M Solow juga menyatakan bahwa faktor yang dominan mempengaruhi pertumbuhan ekonomi adalah modal dan tenaga kerja. Sedangkan kaitannya dengan kemiskinan walaupun faktor pertumbuhan merupakan faktor penting untuk mengurangi kemiskinan namun menurut Ravallion tidak cukup dengan hanya meningkatkan pertumbuhan, karena pada kenyataannya walaupun pertumbuhan ekonomi meningkat akan tetapi tidak semua masyarakat bisa merasakan pertumbuhan tersebut, sebagaimana yang terjadi di beberapa daerah di Indonesia salah satunya Provinsi Riau dalam penelitian Priyarsono (2011) menunjukkan bahwa pertumbuhan ekonomi secara efektif mengurangi kemiskinan, tetapi pada saat yang sama pertumbuhan ekonomi meningkatkan ketidakmerataan pendapatan.

Adanya ketimpangan inilah yang dapat menghambat efektifitas pertumbuhan ekonomi dalam menurunkan kemiskinan. Dengan demikian maka diperlukan pertumbuhan ekonomi yang pro-poor, yaitu pertumbuhan yang memihak dan bisa di rasakan masyarakat miskin (Ravallion, 2006), dimana msayarakat miskin mayoritas berada di sektor pertanian di kawasan pedesaan (Lisna, 2014).

Pertanian sudah lama diakui sebagai suatu instrumen untuk mengurangi kemiskinan, tetapi pertanian juga bisa menjadi sektor terdepan dalam suatu strategi pertumbuhan untuk negara-negara berbasis pertanian. Berdasarkan data BPS (2013) dari 28,55 juta orang miskin di Indonesia, 17,92 juta orang (63\%) hidup dan tinggal di pedesaan dengan pertanian sebagai sumber pendapatan utamanya (Siregar dan Wahyuniarti, 2007). Selain itu, indeks kedalaman kemiskinan dan indeks keparahan kemiskinan pedesaan juga lebih tinggi, kondisi tersebut menunjukkan rendahnya kualitas hidup penduduk miskin di pedesaan.

Hal ini menjadi indikasi bahwa hasil-hasil pembangunan di Indonesia lebih menguntungkan sektor-sektor nonpertanian yang mendominasi struktur ekonomi perkotaan. Oleh karena hal tersbut maka pengentasan kemiskinan di Indonesia akan terwujud jika pembangunan diprioritaskan pada sektor pertanian di kawasan pedesaan (Sumedi, 2013 dan Lisna, 2014).

Pemilihan sektor pertanian menjadi fokus, karena sektor ini memiliki posisi strategis dalam perekonomian dan juga sebagian besar penduduk miskin berada pada sekor pertanian. Dengan demikian pertumbuhan sektor pertanian dapat dikaitkan langsung terhadap pengentasan kemiskinan.

Dalam upaya untuk meningkatkan pertumbuhan ekonomi terutama di sektor pertanian seyogyanya dihubungkan dengan perkembangan faktor-faktor produksinya. Menurut teori Harrod-Domar bahwa investasi terhadap capital stock (barang modal) memegang peranan penting dalam pertumbuhan ekonomi baik di negara maju maupun negara berkembang. Hal ini dikarenakan barang modal seperti infrastruktur dapat memacu pertumbuhan produksi output, seperti jalan dan jembatan dapat meningkatkan akses petani dalam pendistribusian hasil produksi maupun dalam akses menuju tempat kegiatan ekonominya. Sehingga 
dapat memicu terciptanya efisiensi biaya produksi yang nantinya akan menjadikan harga jual produk yang kompetitif, dan aktivitas ekonomi daerah semakin meningkat akibat semakin mudahnya mobilitas faktor produksi dan aktivitas perdagangan daerah akan meningkatkan output perekonomian kemudian meningkatkan pendapatan masyarakatnya (Sutarsono, 2012).

Studi yang terkait telah dilakukan oleh Fan (2002) di India, dimana ditemukan bahwa pengeluaran pemerintah di bidang infrastruktur pertanian seperti pengeluaran untuk R \& $\mathrm{D}$, irigasi, infrastruktur pedesaan (termasuk jalan dan listrik), pendidikan dan pembangunan pedesaan telah berkontribusi terhadap pertumbuhan produktivitas pertanian dan sebagian besar juga berkontribusi terhadap pengurangan kemiskinan.

Selain itu, penelitian dari Calderon et al. (2004) yang menelaah data infrastruktur di lebih dari 100 negara selama periode 1960-2000, dari hasil kajiannya tersebut ditemukan bahwa kuantitas dan kualitas infrastruktur menjadi pendorong pertumbuhan ekonomi, sangat efektif mengurangi kemiskinan, dan sekaligus mengurangi ketimpangan pendapatan. Infrastruktur secara parsial memberikan kontribusi terhadap pertumbuhan output baik pada sektor pertanian maupun nonpertanian.

Selain itu kesenjangan stok infrastruktur antar daerah mempengaruhi output dan kesenjangan di masing-masing daerah tersebut. Oleh karena itu perlunya investasi infrastruktur yang cukup besar sebagai akumulasi modal untuk mendorong ekonomi tumbuh disetiap wilayah. Dengan tesedianya infrastruktur yang mendorong pertumbuhan ekonomi di setiap wilayah setidaknya akan mengurangi ketimpangan sekaligus kemiskinan.

Kebijakan desentralisasi fiskal yang dilakukan sejak tahun 2001 melalui transfer fiskal ke daerah merupakan salah satu kebijakan pemerintah, yang langsung ataupun tidak langsung dapat memberi dampak terhadap kemiskinan di Indonesia. Kebijakan desentralisasi fiskal yang mengalihkan sebagian kewenangan pengelolaan keuangan kepada pemerintah daerah untuk penyediaan layanan publik di daerah diharapkan berdampak terhadap kesejahteraan masyarakat.

Penelitian tentang dampak positif desentralisasi fiskal terhadap pertumbuhan ekonomi telah banyak dilakukan. (Desai et al., 2003; Akai dan Sakata, 2002; Ismail et al., 2004; Iimi, 2005; Bjornestad, 2009). Namun pada hasil penelitian Nanga (2006) menunjukkan bahwa transfer fiskal di Indonesia justru memiliki dampak yang cenderung memperburuk ketimpangan pendapatan dan kemiskinan.

Salah satu bentuk komitmen pemerintah pusat dalam kebijakan desentralisasi fiskal adalah mengalokasikan anggaran transfer fiskal ke daerah dalam APBN, yaitu terdiri dari Dana Bagi Hasil (DBH), Dana Alokasi Umum (DAU), dan Dana Alokasi Khusus (DAK). DAK sebagai salah satu bentuk pendanaan desentraslisasi fiskal, di alokasikan pada dasarnya untuk meningkatkan penyediaan sarana dan prasarana fisik daerah yang menjadi prioritas nasional guna menyerasikan laju pertumbuhan antar daerah dan pelayanan antar sektor. DAK dapat dijadikan kompensasi atas kekurangan pembiayaan pembangunan fisik dan pelayanan masyarakat di daerah.

Pendanaan infrastruktur pekerjaan umum selain berasal dari alokasi APBN 
juga juga berasal dari DAK. Walaupun jumlah DAK sangat kecil (hanya sekitar $7 \%)$ dibandingkan DAU (70\%) dan $\mathrm{DBH}(23 \%)$ dari total dana perimbangan, namun DAK berkontribusi signifikan terhadap pembangunan daerah karena dapat menjadi komponen dari belanja modal (Bappenas, 2011).

Sedangkan peran DAU sendiri tidak dapat dipungkiri bahwa bagi daerah-daerah yang kemampuan fiskalnya rendah terpakai untuk gaji pegawai dan belanja tidak langsung lainnya, yaitu belanja yang tidak berpengaruh langsung terhadap pembangunan. Sehingga DAK memiliki peran strategis dalam pembiayaan pemerintah daerah atau dalam meningkatkan alokasi anggaran pengeluaran daerah.

Berdasarkan uraian di atas, maka tujuan penelitian ini adalah untuk menguji secara empiris efektivitas alokasi transfer anggaran dari pemerintah pusat melalui dan alokasi khusus dan belanja modal dari pemerintah daeah melalui APBD. Indikator efektivitas anggaran dilihat apakah alokasi dana transfer berupa DAK dan belanja modal daerah memiliki pengaruh yang nyata terhadap kinerja fiskal, produk domestik regional bruto (PDRB) dan penyerapan tenaga kerja sektoral, ketimpangan dan kemiskinan desa-kota. Selain itu juga melihat besaran dampak perubahan relatif dan besaran multiplier effect antara DAK dengan belanja modal terhadap PDRB, penyerapan tenaga kerja, ketimpangan dan kemiskinan.

\section{METODE PENELITIAN}

Data Kajian ini menggunakan data panel provinsi yang meliputi: Dana Alokasi Khusus Bidang Infrastruktur (Jalan, Irigasi, dan lainnya) dan Bidang
Pertanian, Belanja Modal, PDRB pertanian dan non pertanian, jumlah tenaga kerja pertanian dan non pertanian, indeks gini dan jumlah penduduk miskin di pedesaan dan perkotaan. Data tersebut berupa data sekunder mulai tahun 2009 sampai 2013 yang dipilih dari 19 provinsi di Indonesia berdasarkan karakteristik rendahnya kapasitas fiskal yang dimilikinya, kemudian provinsi tersebut di klasifikasikan ke dalam 2 kelompok yaitu daerah pertanian tinggi dan pertanian rendah. Klasifikasi ini dilakukan dengan alasan ada perbedaan yang cukup besar terkait karakteristik fiskal, perekonomian, dan kemiskinan antara provinsi pertanian tinggi dan provinsi pertanian rendah.

Klasifikasi dilakukan dengan membandingkan share PDRB pertanian di suatu provinsi dengan ratarata share PDRB pertanian seluruh provinsi periode 2009-2013. Jika share PDRB pertanian lebih besar dari ratarata maka provinsi tersebut diklasifikasikan sebagai provinsi pertanian tinggi, sedangkan jika lebih kecil dari rata-rata diklasifikasikan sebagai provinsi pertanian rendah (Budiyanto, 2014).

Sumber data berasal dari Badan Pusat Statistik, Direktort Jenderal Perimbangan Keuangan Kementerian Keuangan, dan Kementeria Pekerjaan Umum. Data-data tersbut merupakan akumulasi dari data pemerintah kabupaten, kota serta provinsi.

\section{Metode Analisis Data}

Untuk menjawab permasalahan penelitian digunakan model ekonometrika dengan sistem persamaan simultan menggunakan program komputer SAS 9.3. Model dibentuk berdasarkan studi literatur (Nanga, 2006; Sumedi, 2013; Lisna, 2014; dan 
Budiyanto, 2014) serta kerangka teori yang digunakan untuk menentukan keterkaitan antara variabel satu dengan lainnya maka dapat disusun model ekonomtetrika sebagai suatu penyederhanaan yang dapat menggambarkan fenomena nyata. Model yang dibangun dalam penelitian ini terdiri dari 3 blok, yaitu blok kinerja fiskal daerah (pengeluaran dan penerimaan daerah), kinerja perekonomian (PDRB sektoral dan penyerapan tenaga kerja sektoral), ketimpangan dan kemiskinan.

\section{Blok kinerja fiskal}

1. DJLN $_{\text {it }}=\mathrm{a}_{0}+\mathrm{a}_{1}$ KAPFIS $_{\mathrm{it}}+$ $\mathrm{a}_{2} \mathrm{TPOV}_{\mathrm{it}}+\mathrm{a}_{3} \mathrm{LW}_{\mathrm{it}}+\mathrm{a}_{4} \mathrm{D}_{\mathrm{it}}+$ $\mathrm{a}_{5} \mathrm{LDJLN}_{\mathrm{it}}+\mu_{1}$

2. DIRGS $_{\text {it }}=b_{0}+b_{1}$ KAPFIS $_{\text {it }}+$ $\mathrm{b}_{2} \mathrm{TPOV}_{\mathrm{it}}+\mathrm{b}_{3} \mathrm{D}_{\mathrm{it}}+\mathrm{b}_{4} \mathrm{LDIRG}_{\mathrm{it}}+\mu_{2}$

3. DINFLL $_{i t}=c_{0}+c_{1}$ KAPFIS $_{\text {it }}+$ $\mathrm{c}_{2} \mathrm{TPOV}_{\mathrm{it}}+\mathrm{c}_{3} \mathrm{D}_{\mathrm{it}}+\mathrm{c}_{4}$ LDINFL $_{\mathrm{it}}+\mu_{3}$

4. $\mathrm{INFR}_{\mathrm{it}}=\mathrm{DJLN}_{\mathrm{it}}+\mathrm{DIRGS}_{\mathrm{it}}+$ DINFLL $_{i t}$

5. $\mathrm{DAK}_{\mathrm{it}}=\mathrm{INFR}_{\mathrm{it}}+\mathrm{DAKPER}_{\mathrm{it}}+$ DAKLL $_{\text {it }}$

6. $\mathrm{DAPER}_{\mathrm{it}}=\mathrm{DAU}_{\mathrm{it}}+\mathrm{DAK}_{\mathrm{it}}+\mathrm{DBH}_{\mathrm{it}}$

7. $\mathrm{PDD}_{\mathrm{it}}=\mathrm{PAD}_{\mathrm{it}}+\mathrm{DAPER}_{\mathrm{it}}+\mathrm{PDL}_{\mathrm{it}}$

8. PAD $_{\text {it }}=\mathrm{d}_{0}+\mathrm{d}_{1}$ TPDRB $_{\text {it }}+\mathrm{d}_{2}$ PLD $_{\text {it }}$ $+\mathrm{d}_{3} \mathrm{D}_{\mathrm{it}}+\mu_{4}$

9. $\mathrm{KAPFIS}_{\mathrm{it}}=\mathrm{PDD}_{\mathrm{it}}-\mathrm{DAK}_{\mathrm{it}}-\mathrm{DAU}_{\mathrm{it}}-$ $\mathrm{PDL}_{\mathrm{i}}$

10. $\mathrm{BL}_{\mathrm{it}}=\mathrm{MDL}_{\mathrm{it}}+\mathrm{NMDL}_{\mathrm{it}}$

11. $M_{D L} L_{i t}=e_{0}+e_{1} P_{A D} D_{i t}+e_{2} I_{N F R}$ $+\mathrm{e}_{3} \mathrm{DAU}_{\mathrm{it}}+\mathrm{e}_{4} \mathrm{DBH}_{\mathrm{it}}+\mathrm{e}_{5} \mathrm{D}_{\mathrm{it}}+$ $\mathrm{e}_{6} \mathrm{LMDL}_{\mathrm{it}}+\mu_{5}$

12. $\mathrm{PLD}_{\mathrm{it}}=\mathrm{BL}$ it $+\mathrm{BTL}_{\mathrm{it}}$

\section{Blok kinerja perekonomian}
13. $\mathrm{PDRBA}_{i t}=\mathrm{f}_{0}+\mathrm{f}_{1} \mathrm{TKA}_{\mathrm{it}}+$ $\mathrm{f}_{2} \mathrm{DAKPER}_{\mathrm{it}}+\mathrm{f}_{3} \mathrm{DMDL}_{\mathrm{it}}+\mathrm{f}_{4} \mathrm{LLSI}_{\mathrm{it}}$ $+\mathrm{f}_{5} \mathrm{TJLN}_{\mathrm{it}}+\mathrm{f}_{6} \mathrm{D}_{\mathrm{it}}+\mu_{6}$

14. PDRBNA $_{\text {it }} \quad=g_{0}+g_{1}$ TKNA $_{\text {it }}$ $+\mathrm{g}_{2} \mathrm{MDL}_{\mathrm{it}}+\mathrm{g}_{3} \mathrm{TJLN}_{\mathrm{it}}+\mathrm{g}_{4} \mathrm{D}_{\mathrm{it}}+\mu_{7}$

15. $\mathrm{TPDRB}_{\text {it }}=\mathrm{PDRBA}_{\text {it }}+\mathrm{PDRBNA}_{\mathrm{it}}$
16. TKA $=\mathrm{h}_{0}+\mathrm{h}_{1} \mathrm{UPHA}_{\mathrm{it}}+$ $\mathrm{h}_{2} \mathrm{PDRBA}_{\mathrm{it}}+\mathrm{h}_{3} \mathrm{D}_{\mathrm{it}}+\mathrm{h}_{4} \mathrm{LTKA}_{\mathrm{it}}+\mu_{8}$

17. TKNA $_{\text {it }}=\mathrm{i}_{0}+\mathrm{i}_{1} \mathrm{UPHNA}_{\mathrm{it}}+$ $\mathrm{i}_{2} \mathrm{PDRBNA}_{\mathrm{it}}+\mathrm{i}_{3} \mathrm{D}_{\mathrm{it}}+\mathrm{i}_{4} \mathrm{LTKNA}_{\mathrm{it}}+\mu_{9}$

18. $\mathrm{TTK}_{\text {it }}=\mathrm{TKA}_{\mathrm{it}}+\mathrm{TKNA}_{\mathrm{it}}$

19. UPHA $_{\text {it }}=\mathrm{j}_{0}+\mathrm{j}_{1}$ PDRBA $_{\mathrm{it}}+$ $\mathrm{j}_{2}$ TJLN $+\mathrm{j}_{3} \mathrm{D}_{\mathrm{it}}+\mathrm{j}_{4} \mathrm{LUPHA}_{\mathrm{it}}+\mu_{10}$

20. UPHNA $_{\text {it }}=\mathrm{k}_{0}+\mathrm{k}_{1}$ PDRBNA $_{\text {it }}+$ $\mathrm{k}_{2} \mathrm{TJLN}+\mathrm{k}_{3} \mathrm{D}+\mathrm{k}_{4}$ LUPHNA $_{\mathrm{it}}+\mu_{11}$

\section{Blok Ketimpangan dan Kemiskinan}

21. GINI $_{\text {it }}=1_{0}+1_{1}$ SPDRBA $_{\text {it }}+$ $1_{2}$ SPDRBNA $_{i t}+l_{3} D_{\text {it }}+l_{4}$ LGINI $_{\text {it }}$ $+\mu_{12}$

22. $\mathrm{SPDRBA}_{i t}=\mathrm{PDRBA}_{\mathrm{it}} / \mathrm{TPDRB}$ it $* 100$

23. $\mathrm{SPDRBNA}_{i t}=$ PDRBNA $_{\mathrm{i} /} / \mathrm{TPDRB}_{\mathrm{it}} * 100$

24. $\mathrm{POVD}_{\mathrm{it}}=\mathrm{m}_{0}+\mathrm{m}_{1} \mathrm{UPHA}_{\mathrm{it}}+$ $\mathrm{m}_{2}$ PENGDES $_{\text {it }}+\mathrm{m}_{3} \mathrm{GINI}_{\mathrm{it}}+\mathrm{m}_{4} \mathrm{D}_{\mathrm{it}}$ $+\mathrm{m}_{5} \mathrm{LJMPD}_{\mathrm{it}}+\mu_{13}$

25. $\mathrm{POVK}_{\mathrm{it}}=\mathrm{n}_{0}+\mathrm{n}_{1} \mathrm{UPHNA}_{\mathrm{it}}+$ $\mathrm{n}_{2} \mathrm{PENGKOT}_{\mathrm{it}}+\mathrm{n}_{3} \mathrm{GINI}_{\mathrm{it}}+\mathrm{n}_{4} \mathrm{D}_{\mathrm{it}}+$ $\mathrm{n}_{5} \mathrm{LJPMK}_{\mathrm{it}}+\mu_{14}$

26. $\mathrm{TPOV}=\mathrm{POVD}_{\mathrm{it}}+\mathrm{POVK}_{\mathrm{it}}$

Hipotesis yang diharapkan :

$a_{1},<0, a_{2}, a_{3}, a_{4}>0,0<a_{5}<0, b_{1}$, $<0, b_{2}, b_{3}>0,0<b_{4}<0, c_{1},<0, c_{2}, c_{3}>0$, $0<\mathrm{c}_{4}<0, \mathrm{~d}_{1}, \mathrm{~d}_{2}, \mathrm{~d}_{3}>0, \mathrm{e}_{1}, \mathrm{e}_{2}, \mathrm{e}_{3}, \mathrm{e}_{4}, \mathrm{e}_{5}>0$, $0<\mathrm{e}_{6}<0, \mathrm{f}_{1}, \mathrm{f}_{2}, \mathrm{f}_{3}, \mathrm{f}_{4}, \mathrm{f}_{5}, \mathrm{f}_{6}>0, \mathrm{~g}_{1}, \mathrm{~g}_{2}, \mathrm{~g}_{3}$, $\mathrm{g}_{4}>0, \mathrm{~h}_{1}<0, \mathrm{~h}_{2}, \mathrm{~h}_{3}>0,0<\mathrm{h}_{4}>0, \mathrm{i}_{1}<0, \mathrm{i}_{2}$, $\mathrm{i}_{3}>0,0<\mathrm{i}_{4}>0, \mathrm{~g}_{1}, \mathrm{~g}_{2}, \mathrm{~g}_{3}>0,0<\mathrm{g}_{4}>0, \mathrm{k}_{1}, \mathrm{k}_{2}$, $\mathrm{k}_{3}>0,0<\mathrm{k}_{4}>0, \mathrm{l}_{1}, \mathrm{l}_{3}>0, \mathrm{l}_{3}<0,0<\mathrm{l}_{4}>0, \mathrm{~m}_{1}$, $\mathrm{m}_{2}<0, \mathrm{~m}_{3}, \mathrm{~m}_{4}>0,0<\mathrm{m}_{5}>0, \mathrm{n}_{1}, \mathrm{n}_{2}<0, \mathrm{n}_{3}$, $\mathrm{n}_{4}>0,0<\mathrm{n}_{5}>0$

Keterangan :

\begin{tabular}{|c|c|}
\hline DJLN & $\begin{aligned}= & \text { Dana Alokasi Khusus } \\
& \text { Bidang Infratruktur Jalan } \\
& \text { (Rp Juta) }\end{aligned}$ \\
\hline DIRGS & $\begin{aligned}= & \text { Dana Alokasi Khusus } \\
\text { Bidang Infratruktur } & \text { Irigasi }(\mathrm{Rn} \text { Juta })\end{aligned}$ \\
\hline DINFLL & $\begin{aligned} & \text { Irigasi (Kp Juta) } \\
& \text { Dana Alokasi Khusus } \\
& \text { Bidang Infratruktur Lain- } \\
& \text { lain (Rp Juta) }\end{aligned}$ \\
\hline KAPFIS & $=\underset{\text { Juta })}{\text { Kapasitas }}$ Fiskal (Rp \\
\hline
\end{tabular}




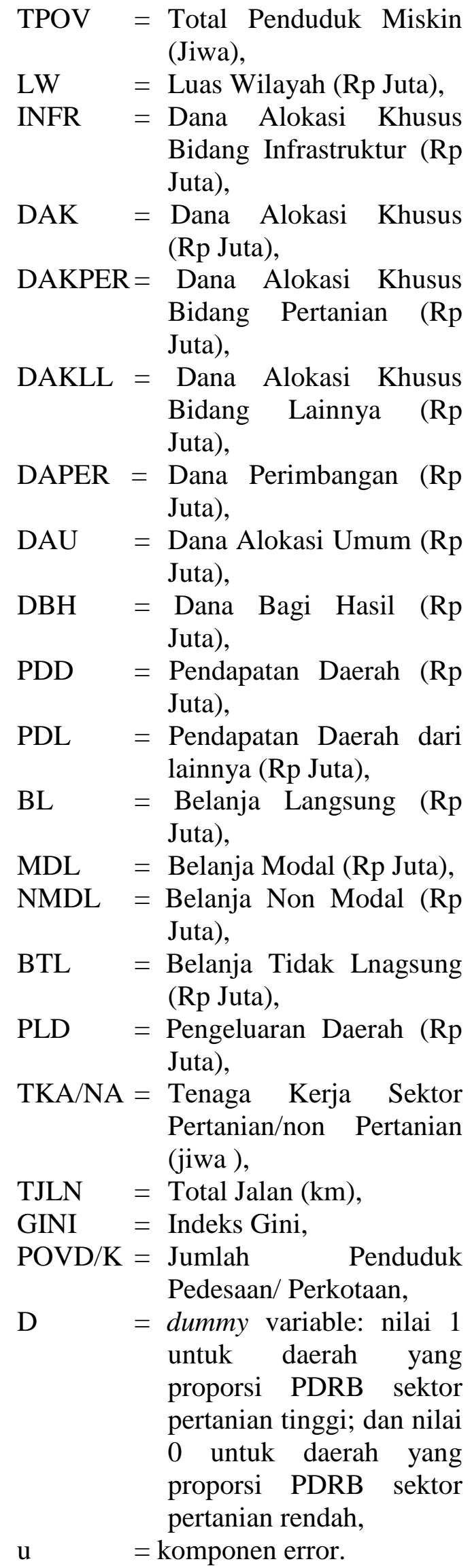

\author{
PENGDES/KOT = Pengeluaran Rata- \\ Rata Penduduk \\ Pedesaan/Perkota \\ an,
PDRBA/NA $=$ Produk Domestik Regional Bruto Sektor Pertanian/Sektor Non Pertanian (juta rupiah),
UPHA/NA = Rata-rata Upah Sektor Pertanian Sektor Pertanian/Non Pertanian(ribu rupiah),
SPDRBA/NA $=$ share Produk Domestik Regional Pertanian/Non Pertanian $(\%)$, \\ Bruto Sektor
}

Identifikasi model ditentukan atas dasar order condition sebagai syarat keharusan dan rank condition sebagai syarat kecukupan. Hasil identifikasi untuk setiap persamaan struktural haruslah exactly identified atau over identified untuk dapat menduga parameter-parameternya.

Syarat kecukupan dituangkan dalam rank condition untuk identifikasi yang menyatakan bahwa dalam suatu persamaan teridentifikasi jika dan hanya jika dimungkinkan untuk membentuk minimal satu determinan bukan nol pada order (G-1) dari parameter struktural peubah yang tidak termasuk dalam persamaan tersebut.

Tahapan identifikasi model meliputi: 26 persamaan $(\mathrm{G})$, yang terdiri dari: 40 variabel atau peubah $(\mathrm{K})$, serta antara 2 sampai 6 variabel dalam suatu persamaan $(\mathrm{M})$; sehingga $\mathrm{K}-\mathrm{M}=34$ dan $\mathrm{G}-1=25$, maka $(\mathrm{K}-\mathrm{M})>(\mathrm{G}-$ 1). Oleh karena itu berdasarkan kriteria order condition maka persamaan 
dinyatakan teridentifikasi secara berlebih (over identified) sehingga dapat diduga parameter-parameternya. Selanjutnya, estimasi model dilakukan dengan metode Two Stage Least Squares (2SLS).

Setelah estimasi model dilakukan maka maka selanjutnya adalah validasi model untuk mengevaluasi apakah nilai esimasi sesuai dengan nilai aktual masing-masing variabel endogen. Jika model sudah di pandang valid maka di lanjutkan ke tahap analisis simulasi kebijakan.

Simulasi pada penelitian adalah simulasi historis periode tahun 20092013. Simulasi I adalah Peningkatan DAK jalan $150 \%$, Simulasi II adalah Peningkatan DAK irigasi $150 \%$, Simulasi III adalah Peningkatan DAK bidang pertanian $75 \%$, dan simulasi IV adalah peningkatan belanja modal $40 \%$

\section{HASIL DAN PEMBAHASAN}

\section{Keragaan dan Pendugaan Model}

Pada bagian ini akan dijelaskan hasil penelitian berdasarkan tanda dan besarannya (magnitude and sign), koefisien determinasi $\left(\mathrm{R}^{2}\right)$, statistik $\mathrm{t}$ dan F. Hasil estimasi model menunjukkan bahwa nilai koefisien determinasi $\left(\mathrm{R}^{2}\right)$ dari tiap-tiap persamaan cukup besar. Sekitar 9 persamaan struktural (65\%) yang memiliki nilai koefisien determinasi lebih dari 0.70 , dan hanya 3 persamaan struktural (21\%) yang memiliki nilai koefisien determinasi kurang dari 0.50 . Dengan demikian secara umum dapat dikatakan bahwa variabel-variabel penjelas yang ada dalam persamaan mampu menjelaskan dengan baik variabel endogen (endogenous variable).

Nilai statistik F cukup besar berkisar antara 2.65 sampai 1449.06 dengan nilai prob. $\mathrm{F}<0.0001$, kecuali variabel upah sektor pertanian yang signifikan pada 0.0402 , yang berarti variasi variabel-variabel penjelas dalam setiap persamaan secara bersama-sama mampu menjelaskan dengan baik variasi variabel endogennya, pada taraf $\alpha=$ 0.0001 dan upah sektor pertanian pada taraf $\alpha=0.04$. Di samping itu, setiap persamaan struktural sebagian besar mempunyai besaran parameter dan tandanya sesuai dengan kriteria teori ekonomi. Beberapa variabel penjelas yang parameter estimasinya tidak sesuai dengan harapan (teori ekonomi) dapat dijelaskan secara logis dan sesuai dengan keadaan di lapang.

Hasil validasi model menunjukkan bahwa secara umum, rata-rata nilai prediksi dari varibel endogenus mendekati rata-rata nilai aktualnya. Hampir semua nilai statistik proporsi bias $\left(\mathrm{U}_{\mathrm{M}}\right)$ mendekati nol, dan nilai proporsi distribusi $\left(\mathrm{U}_{\mathrm{D}}\right)$ mendekati satu, berarti model tidak terdapat bias sistemik. Sedangkan nilai U-Theil's jika mendekati nol maka model dianggap baik, sedangkan jika mendekati satu maka model dianggap kurang mampu menjelaskan data yang sebenarnya.

Hasil validasi menunjukkan hanya persamaan jumlah penduduk miskin, baik di daerah PDRB sektor pertanian tinggi maupun rendah, lebih dari 0.30 . Hal tersebut dikarenakan variasi data variabel penduduk miskin perkotaan sangat besar. Dengan demikian berdasarkan hasil validasi, jika dilihat secara keseluruhan, dapat dikatakan model ini cukup baik digunakan untuk simulasi alternatif kebijakan.

\section{Hasil Estimasi blok kinerja fiskal daerah}

Kinerja fiskal dalam hal ini disajikan dalam persamaan penerimaan dan belanja daerah. Total penerimaan 
pemerintah disajikan dalam persamaan identitas, yang mana merupakan penjumlahan dari pendapatan asli daerah (PAD), dan Dana Perimbangan dari pemerintah pusat (DAPER), dan lain-lain pendapatan PAD yang sah (PADL). Sedangkan Pengeluaran (belanja) daerah juga disajkan dalam persamaan identitas yaitu penjumlahan dari belanja langsung dan tidak langsung.

\section{Dana Alokasi Khusus Bidang Infrastruktur}

Hasil Estimasi menunjukkan bahwa kapasitas fiskal (KAPFIS) yang mencerminkan kemampuan keuangan daerah berpengaruh terhadap besarnya. Daerah yang mempunyai kapasitas fiskal rendah maka mendapatkan alokasi DAK yang lebih besar, dan begitu sebaliknya. Hasil estimasi menunjukkan bahwa kapasitas fiskal berpengaruh negatif terhadap besarnya DAK jalan. Hal yang sama juga terjadi pada persamaan DAK irigasi dan DAK infrastrukrur lainnya dimana kapasitas fiskal juga mempunyai pengaruh negatif dan tidak berbeda nyata pada kedua persamaan tersebut. Hasil penelitian ini sesuai dengan hasil temuan Sumedi (2013). Koefisien parameter kapasitas fiskal yang diperoleh dalam penelitian ini sangat kecil, terutama pada persamaan DAK infrastruktur irigasi sebesar $\quad-0,00039$. Hal ini mengindikasikan bahwa kapasitas fiskal tidak menjadi pertimbangan utama dalam menentukan besarnya DAK infrastruktur yang diberikan kepada daerah, baik itu infrastruktur jalan, irigasi dan infrastruktur lain-lain. Hal ini dikarenakan dalam penentuan DAK terdapat kriteria lainnya, yaitu kriteria khusus dan teknis yang tidak menjadi bagian dalam penelitian ini.
Faktor lainnya adalah jumlah penduduk miskin (TPOV) dimana salah satu peruntukan DAK adalah untuk percepatan pengentasan kemiskinan. Daerah yang memiliki jumlah penduduk miskinnya besar maka mendapatkan DAK infrastruktur yang lebih besar. Koefisien parameter variabel jumlah penduduk miskin dari kedua persamaan pada Tabel 1 mempunyai tanda positif dan tidak berbeda nyata sebagaimana juga yang didapatkan dar penelitian Sumedi (2013). Koefisien parameter pada persamaan DAK jalan dan irigasi mempunyai nilai yang besarnya hampir sama yaitu 0,00691 dan 0,00697. Artinya jika jumlah penduduk miskin meningkat sebanyak 1000 jiwa maka besarnya DAK infrastruktur jalan dan irigasi meningkat sebesar 6,9 juta. Koefisien elastisitas yang juga kecil menunjukkan rendahnya responsibilitas DAK infrastruktur terhadap perubahan jumlah penduduk miskin di suatu daerah

\section{Pendapatan Asli Daerah}

Pendapatan Asli Daerah (PAD) diperoleh dari hasil pajak daerah, hasil retribusi daerah, hasil pengelolaan kekayaan daerah yang dipisahkan dan lain-lain PAD yang sah. Untuk itu, dalam masa desentralisasi seperti ini, pemerintah daerah dituntut untuk bisa mengembangkan dan meningkatkan pendapatan asli daerahnya dengan memaksimalkan sumberdaya yang dimiliki untuk membiayai kegiatan daerah. Besarnya PAD akan menggambarkan kemandirian suatu daerah. Hasil estimais pada Tabel 1 menunjukkan bahwa PAD memberikan respon positif dan berbeda sangat nyata $(\mathrm{P}<0,01)$ terhadap variabel total PDRB. Untuk melihat responsibilitasnya dilihat dari nilai elastisitas, dimana nilai elastisitasnya menunjukkan bahwa apabila total PDRB meningkat sebesar 
10\% maka PAD memberikan respon peningkatan sebesar $6,4 \%$. Hal ini mengindikasikan bahwa total PDRB masih perlu di tingkatkan untuk menambah pendapatan asli daerah.

Selain itu, PAD juga dipengaruhi oleh variabel pengeluaran daerah (PLD), dimana penerimaan merupakan fungsi dari pengeluaran. PLD berpengaruh positif dan berbeda sangat nyata $(\mathrm{P}<0,01)$. Jika pengeluaran daerah naik maka besarnya pendapata asli daerah juga meningkat. Niali elastisitas sebesar 0,38 menunjukkan bahwa perubahan PAD kurang responsif terhadap perubahan variabel PLD. Sedangkan variabel dummy bernilai negatif, hal ini berarti tidak ada perbedaan besarnya PAD antara daerah pertanian tinggi dengan daerah pertanian yang rendah.

\section{Belanja Modal}

Secara teori, kebutuhan fiskal (belanja pemerintah) bukan ditentukan oleh penerimaan daerah namun justru sebaliknya, yaitu penerimaan daerah yang dipengaruhi oleh kebutuhan daerah, seperti disampaikan. Tetapi pada realisasinya, pengeluaran pemerintah ditentukan oleh penerimaan daerah. Oleh karena itu belanja modal daerah dalam penelitian ini diduga dipengaruhi oleh unsur-unsur penerimaan daerah yaitu, DAK infrastruktur, DAU dan DBH. Hasil estimasi menunjukkan bahwa seluruh variabel penjelas yang digunakan berpengaruh positif terhadap belanja modal, hanya DAU yang pengaruhnya tidak signifikan.

Koefisien parameter dan koefisien elastisitasnya mempunyai nilai yang kecil. Hal ini menunjukkan bahwa besarnya DAU yang merupakan komponen terbesar dari dana transfer ke daerah tidak memberikan pengaruh yang nyata terhadap belanja modal.

Berdasarkan hasil temuan Lisna (2014) bahwa setengah dari DAU dipergunakan untuk membiayai gaji pegawai negeri sipil (PNS). Hal ini mengindikasikan bahwa DAU lebih diutamakan untuk kebutuhan administrasi pemerintah daerah atau belanja rutin daripada kebutuhan pembiayaan pembnagunan daerah.

Sementara DAK infrastruktur mempunyai pengaruh paling besar terhadap belanja modal, dan nilai elastisitas jangka panjangnya cukup besar yaitu 0,57. Hal ini dapat diartikan dalam jangka panjang apabila DAK infrastruktur dinaikkan $10 \%$ maka akan menambah belanja modal sebesar 5,7\% .

Tabel 1 Hasil Estimasi dan Elastisitas variabel pada Blok Kinerja Fiskal

\begin{tabular}{lrrr}
\hline Variabel & $\begin{array}{r}\text { Parameter } \\
\text { Estimate }\end{array}$ & $\operatorname{Pr}>|\mathbf{t}|$ & Elastisitas
\end{tabular}




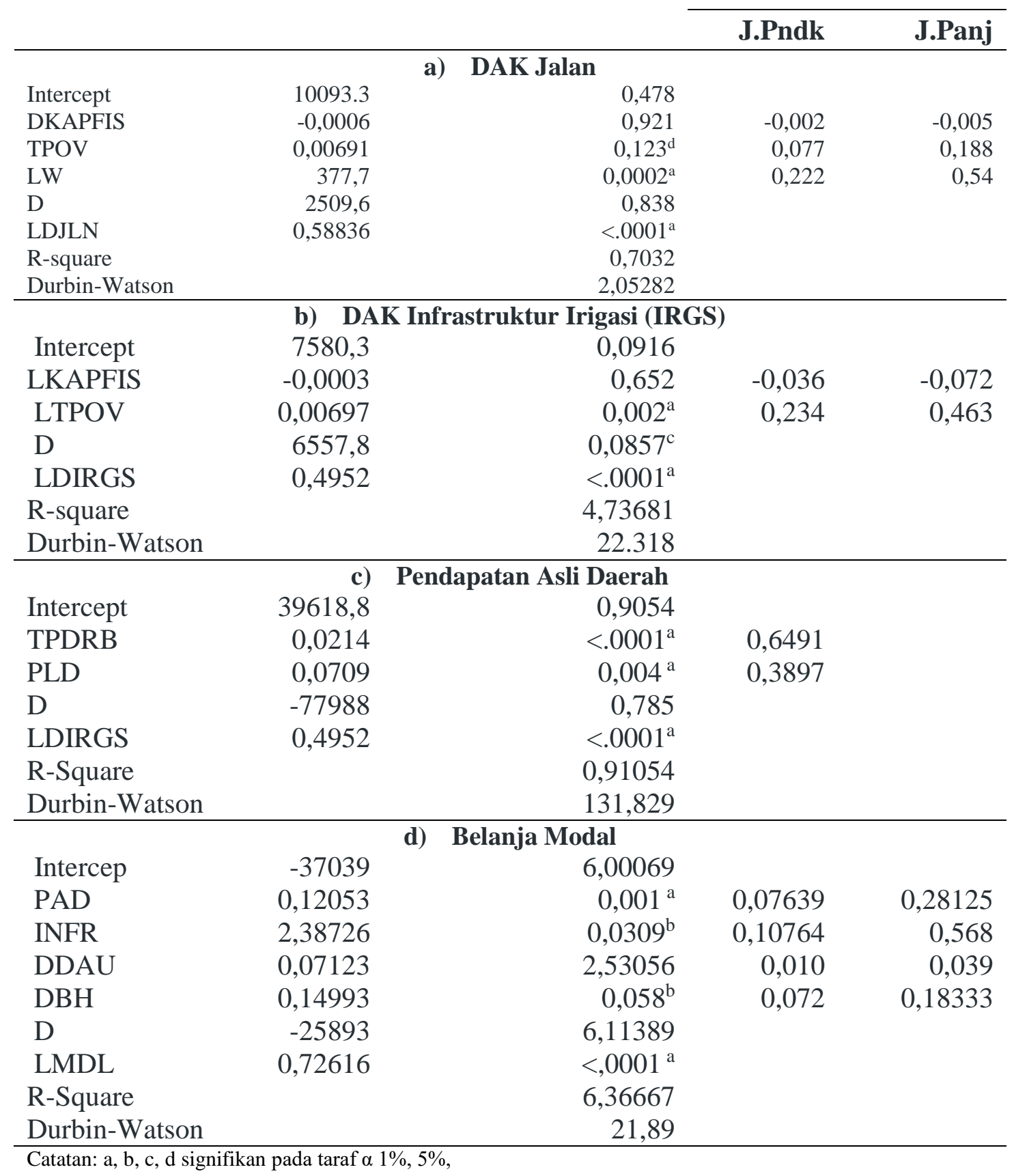

Hasil penelitian ini sesuai dengan temuan lembaga penelitian SMERU yang juga menyatakan bahwa DAK merupakan salah satu sumber pendanaan untuk belanja modal. Hal ini menunjukkan bahwa DAK infrastruktur memberikan pengaruh positif dan signifikan terhadap alokasi pengeluaran daerah melalui belanja modal.

Sementara variabel PAD berpengaruh positif dan berbeda sangat nyata terhadap belanja modal. Hal ini dikarenakan PAD merupakan sumber pembiayaan bagi pemerintahan daerah dalam menciptakan barang modal, termasuk infrastruktur daerah. Semakin baik PAD suatu daerah maka semakin besar pula alokasi belanja modalnya.

\section{Hasil estimasi blok Kinerja} Perekonomian 
Output sektoral Analisis dampak alokasi transfer fiskal bidang infrastruktur terhadap perekonomian didekati salah satunya dengan kinerja output atau Produk Domestik Regional Bruto (PDRB). Secara keseluruhan hasil estimasi parameter memberikan pengaruh positif dan berbeda sangat nyata $(\mathrm{P}<0,01$, hanya variabel total jalan yang tidak memberikan pengaruh secara nyata. Begitu juga pada persamaan PDRB sektor non pertanian semuanya berpengaruh positif dan berbeda nyata. Variabel-variabel tersebut di antaranya dipilih berdasarkan dari teori Solow yang menyatakan bahwa proses pertumbuhan ekonomi dalam jangka panjang merupakan hasil interaksi faktor-faktor produksi yaitu modal, tenaga kerja, dan teknologi.

Hasil estimasi menunjukkan koefisien parameter tenaga kerja pertanian (TKA) berpengaruh positif dan berbeda sangat nyata $(P<0,01)$ serta mempunyai elastisitas terbesar dari variabel-variabel lainnnya di dalam persamaan yaitu $0,6 \%$. Dengan demikian tambahan tenaga kerja di sektor pertanian hendaknya dialokasikan pada daerah-daerah yang mempunyai lahan pertanian yang masih luas.

Hal ini diharapkan dengan tambahan tenaga kerja pada daerah yang lahan pertaniannya luas tersebut akan menjadikan pengusahaan pertanian menjadi lebih intensif sehingga produksi dan produktivitasnya meningkat. Sedangkan pada persamaan PDRB non pertanian koefisien parameter tenaga kerja non pertanian (TKNA) juga mempunyai hubungan positif dan berbeda sangat nyata, serta koefisien elastisitasnya juga mempunyai nilai terbesar dibandingkan dengan variabel lainnya yaitu sebesar $0,85 \%$. Hal ini mengindikasikan bahwa sektor non pertanian masih membutuhkan penambahan tenaga kerja untuk meningkatakn PDRB nya. Dari hasil estimasi kedua persamaan ini menunjukkan bahwa baik sektor pertanian maupun non pertanian samasama bersifat padat karya (labour intensive) sebagaiman telah dijelaskan dalam penelitian Prasetyo (2009) sehingga kebijakan-kebijakan yang bersifat meningkatkan lapangan pekerjaan untuk menyerap tenaga kerja akan lebih efektif dalam peningkatan pertumbuhan ekonomi.

Selanjutnya pengaruh dana alokasi khusus bidang pertanian (DAKPER) terhadap PDRB pertanian berpengaruh positif dan signifikan pada taraf $10 \%$. Nilai koefisien parameter menunjukkan bahwa DAK bidang pertanian memberikan pengaruh yang sangat besar terhadap PDRB pertanian namun mempunyai nilai elastisitasnya kecil yaitu $0,16 \%$.

Koefisien elastisitas yang kecil menunjukkan rendahnya responsibilitas DAK bidang pertanian terhadap perubahan PDRB sektor pertanian. Artinya, DAK bidang pertanian yang lebih besar tidak terlalu berdampak meningkatkan PDRB sektor pertanian. Sementara pengaruh variabel belanja modal terhadap PDRB sektor pertanian mempunyai pengaruh positif dan berbeda sangat nyata, namun mempunyai koefisien parameter estimasi dan elastisitas yang kecil.

Tabel 2 Hasil Estimasi dan Elastisitas Variabel PDRB dan Penyerapan Tenaga Kerja Sektoral

\begin{tabular}{lrrrr}
\hline Variabel & $\begin{array}{r}\text { Parameter } \\
\text { Estimate }\end{array}$ & Pr $>|t|$ & Elastisitas & \\
\hline
\end{tabular}




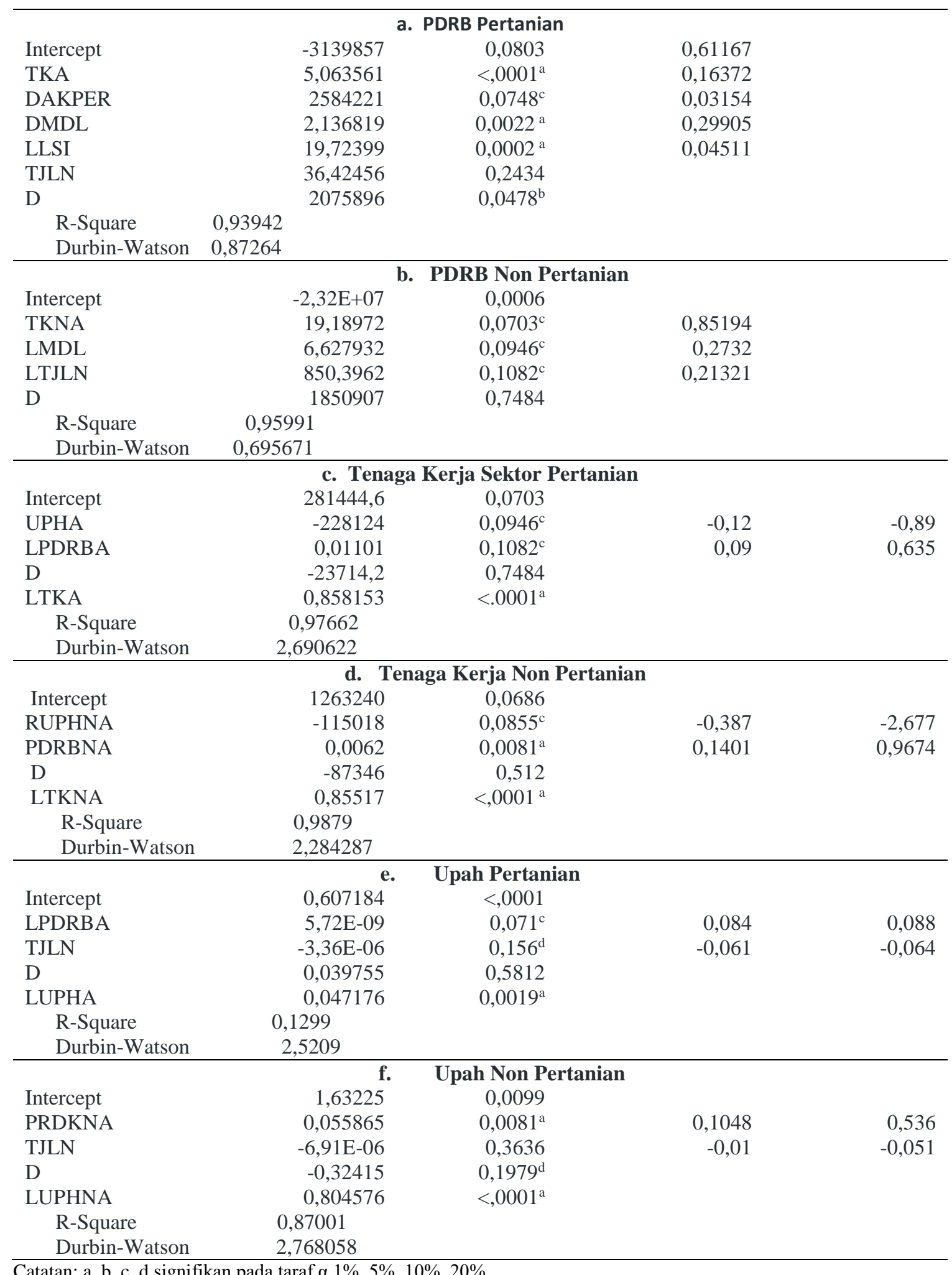

Catatan: a, b, c, d signifikan pada taraf $\alpha 1 \%, 5 \%, 10 \%, 20 \%$.

Berbeda dengan PDRB sektor non pertanian, dimana koefisien parameter dan tingkat elastisitasnya lebih besar daripada sektor pertanian, serta mempunyai pengaruh positif dan signifikan pada taraf $1,0 \%$. Berdasarkan hasil estimasi, jika belanja modal dinaikkan 10\% maka PDRB sektor non 
pertanian memberikan respon peningkatan sebesar 2,7\%. Hal ini mengindikasikan bahwa belanja modal daerah lebih condong pada pembiayaan tehadap sektor non pertanian.

Variabel total panjang jalan mempunyai pengaruh yang positif terhadap PDRB sektor pertanian maupun PDRB sektor non pertanian, namun terhadap PDRB sektor pertanian tidak signifikan. Hal ini diduga bahwa keberadaan panjang jalan belum dimanfaatkan secara maksimal oleh kegiatan di sektor pertanian. Sedangkan pada persamaan PDRB sektor non pertanian nilai estimasi parameter dan elastisitas cukup besar serta secara statistik berbeda sangat nyata.

\section{Tenaga Kerja Sektoral}

Kinerja perekonomian sektoral daerah dapat juga ditinjau dari jumlah tenaga kerja sektoral daerah. Secara statistik dan teori, penyerapan tenaga kerja dipengaruhi oleh upah dan PDRB. Sebagaimana hukum permintaan, jika harga naik maka barang yang diminta akan turun.

Begitu juga tenaga kerja, jika upah naik maka penyerapan tenaga kerja akan turun, upah berpengaruh negatif terhadap sektor pertanian sesuai dengan hipotesis dalam penelitian ini, dan secara statistik bereda nyata. Dalam jangka panjang penurunannya lebih responsif yaitu sebesar $8,9 \%$. Sedangkan pada penyerapan tenaga kerja non pertanian upah yang digunakan merupakan rasio upah terhadap upah tahun sebelumnnya. Hasil estimasinya menunjukkan koefisien parameter negatif dan berbeda nyata $(\mathrm{P}<0,1) \quad$ namun elastisitas penurunannya cukup kecil. Hal ini mengindikasikan kenaikan rata-rata upah akan mendorong pengusaha sektoral untuk mengurangi input tenaga kerja.
Selanjutnya faktor lain yang juga berpengaruh terhadap penyerapan tenaga kerja adalah PDRB masingmasing sektoral, dimana PDRB sektor pertanian pada tahun sebelumnya berpengaruh positif dan berbeda nyata $(\mathrm{P}<0,1)$. Koefisien parameter dan elastisitas yang kecil menunjukkan bahwa pengaruh PDRB sektor pertanian terhadap penyerapan tenaga kerja kecil. Namun dalam jangka panjang kenaikan PDRB sektor pertanian cukup elastis. Sedangkan pengaruh PDRB sektor non pertanian terhadap penyerapan tenaga kerja di sektor non pertanian positif juga berbeda nyata $(\mathrm{P}<0,1)$. Koefisien parameter estimasinya lebih kecil dari pada penyerapan tenaga kerja di sektor pertanian, dan dalam jangka panjang penyerapan tenaga kerja non pertanian sangat responsif dengan nilai elastisitas sebesar $0,96 \%$.

Dummy variabel menunjukkan tidak ada perbedaan penyerapan tenaga kerja di daerah pertanian rendah dan di daerah pertanian tinggi. Di daerah pertanian rendah yang sektor industri dan jasanya relatif lebih maju belum cukup mampu memberikan efek penyerapan tenaga kerja yang besar. Hal ini diduga bahwa sektor industri dan jasa di daerah tersebut hanya membutuhkan tenaga kerja yang mempunyai keterampilan tertentu.

\section{Upah Sektoral}

Informasi tingkat upah sangat penting untuk mengevaluasi tingkat hidup dan kondisi kehidupan tenaga kerja beserta anggota rumahtangganya (Lisna, 2014). Oleh karena itu, penelitian ini menggunakan rata-rata upah sebagai proksi pendapatan untuk menggambarkan daya beli penduduk. Hal ini didasari hipotesis bahwa tingkat upah akan mempengaruhi kemiskinan. Hasil estimasi menunjukkan bahwa PDRB sektor pertanian berpengaruh 
positif dan berbeda nyata $(\mathrm{P}<0,1)$ terhadap rata-rata upah di sektor pertanian. Nilai koefisien parameter dan elastisitas kecil baik dalam jangka pendek maupun jangka panjangnya, hal ini menunjukkan rendahnya responsibilitas PDRB sektor pertanian terhadap perubahan upah sektor pertanian karena diduga perubahan upah masih butuh penyesuaian, tidak mudah mengalami kenaikan atau penurunan. Hasil temuan ini juga sejalan dengan temuan Lisna (2014), pengaruh PDRB terhadap upah juga mempunyai koefisien dan parameter yang kecil.

Sedangkan hasil estimasi pada persamaan upah non pertanian, variabel produktivitas mempunyai elastisitas dalam jangka panjang yang cukup elastisis, artinya dalam jangka panjang upah sektor non pertanian lebih responsif terhadap perubahan produktivitas tenaga kerja sektor non pertanian. Hal ini mengindikasikan bahwa sektor non pertanian lebih mengutamakan produktivitas tenaga kerjanya dalam meningkatkan upah.

\section{Hasil estimasi blok indeks gini dan kemiskinan}

\section{Indeks gini}

Indeks Gini yang merupakan ukuran ketimpangan pendapatan penduduk diduga dipengaruhi oeh kontribusi PDRB sektoral pada total PDRB berdasarkan asumsi hipotesis Kuznets (1955) yaitu sektor tradisional di pedesaan memiliki ketimpangan pendapatan rendah, sedangkan sektor modern di perkotaan memiliki ketimpangan pendapatan tinggi. Dengan demikian, jika share PDRB sektor pertanian sebagai sektor yang mendominasi struktur ekonomi di pedesaan lebih besar diduga menurunkan indeks gini yang berarti ketimpangan pendapatan lebih rendah. Namun, jika share PDRB non pertanian sebagai sektor yang mendominasi struktur ekonomi di perkotaan lebih besar diduga meningkatkan Indeks Gini yang berarti ketimpangan pendapatan semakin besar.

Hasil estimasi indeks gini walaupun tidak signifikan, koefisien PDRB pertanian yang bertanda negatif menunjukkan bahwa meningkatnya PDRB sektor pertanian akan menurunkan ketimpangan. Dilihat dari nilai elastisitasnya, jika share PDRB pertanian di tingkatkan sebesar $10 \%$ maka akan menurunkan tingkat ketimpangan sebesar $0,2 \%$, dimana saat ini indeks gini sudah mencapai $4,1 \%$, angka tersebut cukup besar.

Tabel 3 Hasil Estimasi dan Elastisitas Variabel Indek Gini, Jumlah Penduduk Miskin Pedesaan dan Perkotaan

$\begin{array}{llll}\text { Variabel } & \text { Parameter } & \text { Elastisitas }\end{array}$




\begin{tabular}{|c|c|c|c|c|}
\hline \multirow{2}{*}{\multicolumn{3}{|c|}{ estimate }} & \multirow{3}{*}{ J.Pndk } & \multirow[b]{2}{*}{ J.Panj } \\
\hline & & & & \\
\hline \multicolumn{4}{|c|}{ a. Indeks Gini } & \\
\hline LSPDRBA & $-0,0004$ & 0,6447 & $-0,02$ & \\
\hline GSPDRBNA & 0,00592 & $0,165^{\mathrm{d}}$ & 0,003 & \\
\hline $\mathrm{D}$ & $-0,02883$ & $0,0157^{\mathrm{b}}$ & & \\
\hline R-Square & 0,23452 & & & \\
\hline Durbin-Watson & 0,94305 & & & \\
\hline \multicolumn{5}{|c|}{ b. Jumlah Penduduk Miskin di Pedesaan } \\
\hline Intercept & 204134 & 0,1923 & & \\
\hline UPHA & -170825 & $0,057^{\mathrm{b}}$ & $-0,203$ & $-2,993$ \\
\hline LPENG & & & & \\
\hline DES & $-7169,8$ & 0,7885 & $-0,035$ & $-0,522$ \\
\hline GGINI & 547,229 & 0,7423 & 0,0017 & 0,026 \\
\hline $\mathrm{D}$ & 10183,2 & 0,8364 & & \\
\hline LPOVD & 0,93189 & $<.0001^{\mathrm{a}}$ & & \\
\hline R-Square & 0,96608 & & & \\
\hline Durbin-Watson & 2,635565 & & & \\
\hline \multicolumn{5}{|c|}{ c. Jumlah Penduduk Miskin di Perkotaan } \\
\hline Intercept & 2959071 & $<.0001$ & & \\
\hline UPHNA & $-86572,1$ & $0,012^{\mathrm{b}}$ & $-2,1503$ & \\
\hline LPENGKOT & -129319 & $0,078^{\mathrm{a}}$ & $-1,5966$ & \\
\hline DGINI & 83653,55 & 0,2307 & $-0,0163$ & \\
\hline $\mathrm{D}$ & -883640 & $<.0001^{\mathrm{a}}$ & & \\
\hline R-Square & 0,44036 & & & \\
\hline Durbin-Watson & 0,624955 & & & \\
\hline
\end{tabular}

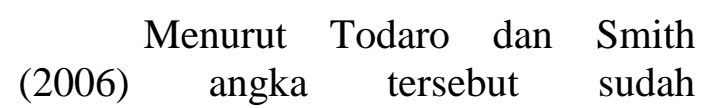
mencerminkan distribusi pendapatan masyarakat yang relatif tidak merata. Sedangkan share PDRB sektor non pertanian berpotensi meningkatkan ketimpangan karena nilai koefisien parametrer nya bertanda positif, namun respon meningkatnya indeks gini akibat peningkatan share PDRB non pertanian dilihat dari nilai koefisien elastisitasnya memberikan pengaruh yang kecil. Variabel dummy bertanda negatif yang berarti bahwa indeks gini di daerah pertanian tinggi dan di daerah pertanian rendah tidak ada perbedaan yang nyata

\section{Kemiskinan di Pedesaan dan di Perkotaan}

Hasil estimasi dari persamaan jumlah penduduk miskin di pedesaan bertanda negatif menunjukkan bahwa rata-rata upah sektor pertanian dan pengeluaran penduduk perkapita pedesaan dapat menurunkan jumlah penduduk miskin pedesaan. Namun variabel pengeluran penduduk tidak signifikan.

Dalam jangka panjang pengaruh variabel upah sangat elastis, bahkan dapat menurunkan jumlah penduduk miskin di pedesaan hingga mencapai $29 \%$ jika upah dinaikkan sebesar $10 \%$. Hal yang sama juga terjadi pada persamaan jumlah penduduk msikin di perkotaan, dimana upah sektor non pertanian dan pengeluaran penduduk perkotaan mempunyai pengaruh yang negatif dan signifikan. Temuan ini 
sejalan dengan penelitian Nanga (2006) dan Lisna (2014).

Selanjutnya pengaruh variabel indeks gini yang menggambarkan kondisi ketimpangan suatu daerah dan berdampak terhadap kemiskinan, berdasarkan hasil estimasi menunjukkan hubungan yang positif dengan jumlah penduduk miskin pedesaan maupun perkotaan, hal ini mengindikasikan bahwa jika nulai indeks gini meningkat maka akan menyebabakan jumlah penduduk miskin semakin meningkat. Hal ini dikerenakna indeks gini yang besar dapat mengurangi keefektifan pertumbuhan ekonomi dalam mengentaskan kemsikinan.

Akan tetapi dilihat dari koefisien elastisitasnya menunjukkan bahwa besarnya perubahan indeks gini tidak terlalu mempunyai dampak terhadap perubahan jumlah penduduk miskin baik dipedesaan maupun di perkotaan. Namun dalam jangka panjang respon jumlah penduduk miskin di pedesaan terhadap indeks gini mempunyai nilai koefisien relatif besar, dimana jika indeks gini meningkat $10 \%$ maka jumlah penduduk miskin diperkotaan meningkat sebesar $0,2 \%$.

Penduduk miskin pedesaan pada tahun sebelumnya (t-1) mempunyai pengaruh yang signifikan terhadap besarnya jumlah penduduk miskin tahun berjalan $(\mathrm{t})$. Variabel dummy pada persamaan jumlah penduduk miskin dipedesaan berhubungan positif, artinya ada perbedaan jumlah penduduk miskin pedesaan di daerah pertanian tinggi dan rendah, dimana dari hasil temuan ini dapat dijelaskan bahwa jumlah penduduk miskin pedesaan lebih besar di daerah pertanian tinggi. Sedangkan jumlah penduduk miskin perkotaan menunjukkan bahwa baik di daearh pertanian tinggi maupun di daerah pertanian rendah tidak ada perbedaan yang nyata, artinya jumlah penduduk miskin perkotaan sama besarnya pada kedua daerah tersebut.

\section{Hasil Simulasi}

\section{1) Peningkatan DAK infrsaruktur Jalan}

Peningkatan DAK bidang infrastruktur jalan sebesar $150 \%$ dapat meningkatkan besarnya alokasi DAK bidang infrastruktur, total DAK, dana perimbangan, pendapatan daerah, dan pengeluaran pemerintah daerah baik di daerah pertanian tinggi maupun daerah pertania rendah. Meningkatnya besarnya kinerja pemerintah tetapi peningkatan variabel tersebut lebih besar terjadi di daerah pertanian tinggi dibandingkan di daerah pertanian rendah.

Selain itu juga dapat meningkatkan PDRB dan upah sektoral. Akibat dari kenaikan tingkat upah tersebut maka menurunkan penyerapan tenaga kerja khususnya sektor pertanian baik di daerah pertanian rendah maupun daerah pertanian tinggi. Sedangkan penyerapan tenaga kerja pada sektor non pertanian semakin meningkat, sehingga adanya peningkatan penyerapan tenaga kerja sektor non pertanian yang porsinya lebih besar dibandingkan dengan penurunan penyerapan tenaga kerja sektor pertanian maka total penyerapan tenaga kerja meningkat.

Indeks gini di dearah pertanian terjadi penurunan sebesar 0,0002\%, karena share PDRB pertanian terhadap total PDRB di dearah pertanian semakin meningkat, sehingga terjadi penurunan ketimpangan. Sedangkan di daerah pertanian tinggi tidak ada perubahan indeks gini, sehingga ketimpangan di daerah tersebut tetap dan selanjutnya dapat berdampak terhadap penurunan jumlah penduduk miskin yang berada pada derah pertanian tinggi dan pertanian rendah. 


\section{2) Peningkatan DAK infrsaruktur Irigasi}

Simulasi pada DAK bidang irigasi sebagaimana pada simulasi peningkatan DAK jalan, simulasi pada DAK irigasi dapat meningkatkan PDRB sektor pertanian lebih besar dari pada PDRB sektor non pertanian baik di daerah pertanian rendah maupun pertanian tinggi. Sedangkan jika dilihatnya berdasarkan klasifikasi daerah, maka peningkatan PDRB sektoral di daerah pertanian tinggi lebih besar di bandingkan di daerah pertanian rendah. Hal ini terjadi sebagai akibat dari peningkatan DAK irigasi yang mengindikasikan bahwa peningkatan DAK irigasi sangat berdampak positif terhadap pembangunan pertanian maupu pembangunan nasional kedepannya.

Kemudian jika dilihat dampak simulasi DAK irigasi terhadap penyerapan tenaga kerja, maka justru tenaga kerja sektor pertanian mengalami penurunan di kedua klasifikasi daerah tersebut, hal ini diduga karena adanya kenaikan upah pada sektor pertanian, dimana berdasarkan hasil estimasi PDRB sektor pertanian berpengaruh signifikan terhadap upah sektor pertanian, kemudian upah sektor pertanian sangat signifikan mempengaruhi penyerapan tenaga kerja sektor pertanian. Namun karena penurunan tenaga kerja sektor pertanian masih lebih kecil daripada peningkatan tenaga kerja sektor non pertanian sehingga penyerapan tenaga kerja total tetap mengalami peningkatan.

Dampak terhadap indeks gini dapat dilihat dari penurunan atau peningkatan dari share PDRB sektoralnya, jika sektor pertanian share nya mengalami peingkatan maka indeks gini nya akan menurun, dan sebaliknya. Hal ini dapat dilihat di daerah pertanian rendah, karena share PDRB sektor pertanian meningkat maka ketimpangan indeks gini turun sebesar 0,0002\%, sedangkan pada sektor non pertanian tinggi, indeks gini nya tidak mengalami perubahan, kondisi ini menggambarkan bahwa ketimpangan di daerah tersebut tetap. Sedangkan dampaknya terhadap kemiskinan, baik kemiskinan di pedesaan maupun diperkotaan, baik yang berada di daerah pertanian tinggi maupun rendah jumlah kemiskinan totalnya mengalami penurunan.

\section{3) Peningkatan DAK bidang pertanian}

Sedangkan DAK pertanian (DAKPER) terhadap kinerja fiskal menunjukkan dampak negatif terhadap besarnya dana perimbangan, DAK total, dan DAK infrastruktur (kecuali pada DAK irigasi). Hal ini mengindikasikan bahwa persentase kenaikan DAK pertanian sebesar $75 \%$ dalam simulasi ini akan sangat mengurangi porsi DAK infrastruktur terutama DAK jalan, dimana DAK jalan mempunyai porsi tertinggi dalam DAK infrastruktur, yaitu $60,4 \%$. Sehingga hal ini wajar ketika DAK infrastruktur menurun yang selanjutnya juga menurunkan DAK total (porsi DAK infrastruktur terhadap DAK total sebesar 30,6\%), dan akibatnya juga berdampak terhadap penurunan dana perimbangan.

Saat dana perimbangan mengalami penurunan, sebaliknya pendapatan asli daerah (PAD) mengalami peningkatan yang cukup besar yaitu $18,5 \%$ ( pada daerah pertanian tinggi) dan 40,8\% (pada daerah pertanian rendah). Hasil temuan dapat menjelaskan bahwa penambahan DAK pertanian sebesar $75 \%$ dalam penelitian ini dapat mengurangi ketergantungan daerah terhadap pusat yang dibuktikan dengan menurunnya dana perimbangan, tapi disisi lain PAD 
mengalami peningkatan yang cukup besar, dimana kedua variabel tersebut menjadi komponen dari pendapatan daerah. Oleh karena peningkatan PAD lebih besar daripada penurunan dana perimbangan maka pendapatan daerah dalam simulasi ini tetap mengalami peningkatan baik di daerah pertanian tinggi maupun rendah.

Selanjutnya dampak terhadap kinerja perekonomian, menunjukkan bahwa peningkatan PDRB sektor pertanian jauh lebih kecil dibandingkan PDRB sektor non pertanian baik di dearh pertanian tinggi atau rendah. Berdasarkan hasil estimasi nilai elastisitas dari DAK pertanian terhadap PDRB sektor pertanian cukup kecil, yaitu hanya $0,16 \%$.

Sedangkan peningkatan PDRB sektor non pertanian lebih besar dapat dijelaskan dari pengaruh belanja modal. Dimana dari hasil estimasi menunjukkan koefisien parameter dan nilai elastisitas belanja modal lebih besar dibandingkan pengaruhnya terhadap PDRB sektor pertanian. Dari temuan sebelumnya juga menunjukkan bahwa DAK pertanian memberikan dampak yang cukup besar terhadap variabel PAD, dimana PAD ini merupakan salah satu faktor penentu dalam menentukan belanja modal.

Upah sektor pertanian tidak mengalami perubahan dari adanya dampak DAK pertanian, hal ini diduga karena peningkatan PDRB yang kecil dan juga pada dasarnya upah bersifat kaku dan lebih ditentukan dari pihak perusahaan. Jika dibandingkan dari penelitian sebelumnya (Lisna, 2014) bahwa PDRB pertanian yang lebih besar menyebabkan perbaikan upah riil pertanian. Kemudian hal ini juga berdampak pada tidak berubahnya penyerapan tenaga kerja sektor pertanian dan jumlah kemiskinan pedesaan pada daerah pertanian tinggi.
Akibat semakin meningkatnya kapasitas fiskal tersebut maka sebagaimana hasil temuan sebelumnya bahwa semakin besar kapasitas fiskal suatu daerah maka mendapatkan dana alokasi dari pusat atau transfer dana dari pemerintah pusat semakin kecil, oleh karena itu DAK infrastruktur, DAK total dan dana perimbangan mengalami penurunan. Hasil temuan ini menunjukkan bahwa dengan adanya peningkatan belanja modal sebesar $40 \%$ oleh pemerintah daerah maka akan meningkatkan perekonomian daerah secara signifikan.

Walaupun terlihat bahwa upah sektor pertanian pada pertanian tinggi dan tenaga kerja pertanian pada pertanian rendah menurun, serta share PDRB pertanian di kedua klasifikasi daerah menurun namun secara totalnya mengalami peningkatan. Hal ini dapat dijelaskan bahwa baik di pertanian tinggi maupun rendah belanja modal untuk pembiayaan sektor pertanian berdasarkan hasil estimasi masih sangat kecil jika dibandingkan dengan sektor non pertanian. Sedangkan dampaknya terhadap jumlah penduduk miskin secara total baik di daerah pertanian tinggi dan rendah semuanya mengalami penurunan.

Secara keseluruhan hasil simulasi dalam penelitian ini menunjukkan bahwa sektor non pertanian selalu tumbuh lebih besar dari pada sektor pertanian sebagaimana hasil temuan Yudhoyono (2004) bahwa Simulasi model simultan yang digunakan terhadap pengeluaran pemerintah untuk infrastruktur berdampak positif terhadap pertumbuhan dan penyerapan tenaga kerja. Namun, dampak pengeluaran pemerintah dalam infrastruktur terhadap pertumbuhan ekonomi dan penyerapan tenaga kerja, relatif lebih besar di sektor non pertanian dibandingkan sektor pertanian 
Tabel 4 Hasil Simulasi Model pada Pertanian Tinggi

\begin{tabular}{|c|c|c|c|c|}
\hline Variabel & Simulasi 1 & simulasi 2 & Simulasi 3 & Simulasi 4 \\
\hline \multicolumn{5}{|c|}{ Blok Kinerja Fiskal } \\
\hline DAK Infra Jalan & - & $-0,13$ & $-0,12$ & $-13,2$ \\
\hline DAK Infra Irigasi & 0 & - & 0 & $-0,7$ \\
\hline DAK Infra lain-lain & -1 & $-0,399$ & $-0,08$ & $-4,8$ \\
\hline DAK Infrastruktur & 1580,3 & 543,3 & $-0,2$ & $-18,7$ \\
\hline Total DAK & 1580,3 & 543,3 & $-0,2$ & 21,7 \\
\hline Dana Perimbangan & 1580,3 & 543,3 & $-0,2$ & 351,7 \\
\hline Pendapatan Asli Daerah & 464,1 & 171,8 & 18,5 & 2065,3 \\
\hline Kapasitas Fiskal & 464,1 & 171,8 & 18,5 & 2108,4 \\
\hline Pendapatan Daerah & 2044,5 & 715,1 & 18,4 & 2708,7 \\
\hline Modal & 3828,7 & 1317,7 & 1,8 & 0 \\
\hline Belanja Langsung & 3828,7 & 1317,7 & 1,8 & 9233,7 \\
\hline Pengeluaran Daerah & 3828,7 & 1317,7 & 1,8 & 9531,2 \\
\hline \multicolumn{5}{|c|}{ Blok Perekonomian } \\
\hline PDRB Pertanian & 8128,2 & 2797,9 & 4,5 & 2331,8 \\
\hline PDRB Non Pertanian & 854 & 854,3 & 854,3 & 62457,4 \\
\hline Total PDRB & 8982,5 & 3652,3 & 858,8 & 64789,3 \\
\hline Upah Pertanian & $4,60 \mathrm{E}-05$ & $1,60 \mathrm{E}-05$ & 0 & $-1,00 \mathrm{E}-05$ \\
\hline Upah Non Pertanian & $9,00 \mathrm{E}-06$ & $9,00 \mathrm{E}-06$ & $9,00 \mathrm{E}-06$ & 0,0024 \\
\hline Tenaga Kerja Pertanian & $-10,6$ & $-3,7$ & 0 & 130,1 \\
\hline Tenaga Kerja Non Pertanian & 44,5 & 44,5 & 44,5 & 3126 \\
\hline Total Tenaga Kerja & 33,9 & 40,9 & 44,5 & 442,63 \\
\hline share PDRB Pertanian & 0,013 & 0,0033 & $-0,002$ & $-0,042$ \\
\hline share PDRB Non Pertanian & $-0,013$ & $-0,0033$ & 0,002 & 0,042 \\
\hline \multicolumn{5}{|c|}{ Blok Ketimpangan dan Ketimpangan } \\
\hline Indeks Gini & $-0,0002$ & $-0,0002$ & $-0,00018$ & $-0,00018$ \\
\hline Jumlah Pdd Miskin Pedesaan & $-7,9$ & $-2,7$ & 0 & 72,83 \\
\hline Jumlah Pdd Miskin Perkotaan & $-16,3$ & $-16,3$ & $-16,29$ & $-233,7$ \\
\hline Total Penduduk Miskin & $-24,2$ & $-19,02$ & $-16,29$ & $-160,9$ \\
\hline
\end{tabular}

Tabel 5 Hasil Simulasi Model pada Pertanian Rendah

\begin{tabular}{lllll}
\hline Variabel & Simulasi 1 & simulasi 2 & Simulasi 3 & Simulasi 4 \\
\hline
\end{tabular}




\begin{tabular}{|c|c|c|c|c|}
\hline \multicolumn{5}{|c|}{ Blok Kinerja Fiskal } \\
\hline DAK Infra Jalan & - & $-0,15$ & $-0,13$ & $-1,5$ \\
\hline DAK Infra Irigasi & 0 & - & 0 & 0 \\
\hline DAK Infra lain-lain & $-1,3$ & $-0,53$ & $-0,14$ & $-7,8$ \\
\hline DAK Infrastruktur & 1955,4 & 666,5 & $-0,3$ & $-9,3$ \\
\hline Total DAK & 1955,4 & 666,5 & $-0,3$ & $-9,3$ \\
\hline Dana Perimbangan & 1955,4 & 666,5 & $-0,3$ & $-9,3$ \\
\hline Pendapatan Asli Daerah & 592,1 & 228,7 & 40,8 & 3552,1 \\
\hline Kapasitas Fiskal & 592,1 & 228,7 & 40,8 & 3552,1 \\
\hline Pendapatan Daerah & 2547,5 & 895,6 & 40,5 & 3542,8 \\
\hline Modal & 4739,4 & 1618,6 & 4,3 & 0 \\
\hline Belanja Langsung & 4739,4 & 1618,6 & 4,3 & 16201,3 \\
\hline Pengeluaran Daerah & 4739,4 & 1618,6 & 4,3 & 16201,3 \\
\hline \multicolumn{5}{|c|}{ Blok Perekonomian } \\
\hline PDRB Pertanian & 10062,7 & 3437,8 & 10,9 & 3216,1 \\
\hline PDRB Non Pertanian & 1900 & 1900 & 1900 & 108900 \\
\hline Total PDRB & 11900 & 5300 & 1800 & 112000 \\
\hline Upah Pertanian & $5,70 \mathrm{E}-05$ & $1,90 \mathrm{E}-05$ & 0 & $1,80 \mathrm{E}-05$ \\
\hline Upah Non Pertanian & 0,0002 & 0,0002 & 0,0003 & 0,0025 \\
\hline Tenaga Kerja Pertanian & $-13,1$ & $-4,5$ & $-0,02$ & $-4,2$ \\
\hline Tenaga Kerja Non Pertanian & 97,7 & 97,7 & 97,7 & 599,3 \\
\hline Total Tenaga Kerja & 84,6 & 93,2 & 97,7 & 595,1 \\
\hline share PDRB Pertanian & 0,0006 & $-0,0103$ & $-0,0145$ & $-0,0319$ \\
\hline share PDRB Non Pertanian & $-0,0005$ & 0,0103 & 0,0145 & 0,0319 \\
\hline \multicolumn{5}{|c|}{ Blok Ketimpangan dan Ketimpangan } \\
\hline Indeks Gini & 0 & 0 & 0 & 0 \\
\hline Jumlah Pdd Miskin Pedesaan & $-9,8$ & $-3,4$ & $-0,02$ & $-3,15$ \\
\hline Jumlah Pdd Miskin Perkotaan & $-19,4$ & $-19,4$ & $-19,39$ & $-214,4$ \\
\hline Total Penduduk Miskin & $-29,2$ & $-22,7$ & $-19,41$ & $-217,6$ \\
\hline
\end{tabular}

\section{KESIMPULAN}

Berdasarkan hasil estimasi parameter dan simulasi kebijakan dapat disimpulkan bahwa:

1. Kinerja perekonomian sektoral dapat dilihat dari output atau PDRB sektor pertanian dan non pertanian. Output sektor pertanian ditentukan oleh tenaga kerja pertanian, DAK pertanian, selisih belanja modal dengan tahun sebelumnya, luas wilayah, dan total panjang jalan. Sedangkan sektor non pertanian ditentukan oleh tenaga kerja non pertanian, belanja modal pada tahun sebelumnya, dan total panjang jalan pada tahun sebelumnya. Dilihat dari penyerapan tenaga kerja, maka penyerapan tenaga kerja sektor pertanian ditentukan oleh upah sektor pertanian dan PDRB sektor pertanian pada tahun sebelumnya. Sedangkan Tenaga kerja sektor non pertanian ditentukan oleh rasio upah terhadap upah tahun sebelumnya dan PDRB sektor non pertanian. Upah sektoral ditentukan oleh PDRB sektoral dan total panjang jalan, dimana total panjang jalan berpengaruh negatif namun tidak signifikan.

2. Indeks gini ditentukan oleh share PDRB sektor pertanian dan share PDRB sektor non pertanian. Jumlah penduduk miskin di pedesaan dan pekotaan ditentukan oleh upah sektoral, pengeluaran penduduk, dan indeks gini.

3. Peningkatan DAK jalan baik didaerah pertanian tinggi maupun rendah meningkatkan kapasitas fiskal dan pendapatan daerah, menurunkan jumlah tenaga kerja pertanian, tetapi meningkatkan share PDRB sektor 
pertanian, menurunkan jumlah kemiskinan dipedesaan dan perkotaan, menurunkan ketimpangan di daerah pertanian tinggi namun di daerah pertanian rendah ketimpangan tidak mengalami perubahan. Sedangkan Peningkatan DAK irigasi meningkatkan kinerja fiskla daerah, menurunkan tenaga kerja sektor pertanian, dan menurunkan kemiskinan pada kedua klasifikasi daerah. Di daerah pertanian tinggi menurunkan menurunkan PDRB sektor non pertanian dan indeks gini. Sedangkan di daerah pertanian rendah berdampak menurunkan share PDRB sektor pertanian dan ketimpangan tidak mengalami perubahan.

4. Peningkatan DAK pertanian menurunkan besarnya dana perimbangan dalam kinerja fiskal, menurunkan tenaga kerja pertanian pada daerah pertanian rendah, namun tenaga kerja di daerah pertanian tinggi tidak mengalami perubahan, menurunkan share PDRB pertanian, menurunkan indeks gini (hanya di daerah pertanian tinggi) dan menurunkan kemiskinan, namun jumlah penduduk miskin di pedesaan tidak mengalami perubahan. Pada simulasi peningkatan DAK pertanian justru menurunkan PDRB pertanian.

5. Hasil simulasi pada peningkatan belanja modal berdampak pada penurunan beberapa variabel kinerja fiskal yaitu DAK infrastruktur (jalan, irigasi, dan lainny). peningkatan belanja modal maka dapat memberikan dampak terhadap peningkatkan kinerja perekonomian suatu daerah melalui kenaikan output sektoral dalam hal ini sektor pertanian dan non pertanian. Upah sektor pertanian pada pertanian tinggi dan tenaga kerja pertanian pada pertanian rendah mengalami penurunan, serta share PDRB pertanian dikedua klasifikasi daerah menurun namun secara totalnya mengalami peningkatan. Sedangkan dampaknya terhadap jumlah penduduk miskin secara total baik di daerah pertanian tinggi dan rendah semuanya mengalami penurunan. Secara keseluruhan peningkatan variabel-variabel dalam model akibat simulasi dalam penelitian selalu lebih besar terjadi pada daerah pertanian rendah daripada daerah pertanian tinggi.

Oleh karena itu untuk mencapai tujuan pembangunan ekonomi maka pemerintah pusat kembali harus menginjeksikan dana langsung ke daerah lewat DAK bidang infrastruktur dan pertanian yang ditujukan untuk memperbaiki layanan dasar di daerah dalam rangka percepatan pembangunan daerah dan pencapaian sasaran prioritas nasional, yaitu menurunkan kemiskinan, ketimpangan pendapatan, penyerapan tenaga kerja dan proporsi penduduk miskin dipedesaan, dimana hal ini mengindikasikan pertumbuhan propoor. Selain itu. mengingat dalam beberapa tahun terakhir ini penurunan kemiskinan melambat dan indeks gini meningkat maka sebaiknya pemerintah daerah melakukan revisi struktur anggaran belanja yang dapat mengurangi jumlah kemiskinan melalui peningkatan belanja modal yang dampaknya langsung terhadap sektor riil terutama sektor pertanian.

\section{DAFTAR PUSTAKA}

Akai N. and M. Sakata. 2002. Fiscal Decentraliztion Countributes to Economic Growth: Evidence from State-Level Cross-Section Data 
for the United States. Journal of Urban Economics, 52:93-108.

Bappenas. 2011. Analisis Perspektif, Permasalahan dan Dampak Dana Alokasi Khusus (DAK). White Paper

[BPS] Badan Pusat Statistik. 2013. Statistik Indonesia 2003. Jakarta: BPS.

Bjornestad L. 2009. Fiscal Decentralization, Fiscal Incentives, and Pro-Poor Outcomes: Evidence from Viet Nam. ADB Economics Working Paper Series No. 168, Asian Development Bank, Metro Manila.

Budiyanto. 2014. Dampak Pengeluaran Pemerintah Daerah untuk Sektor Pertanian dan Industri terhadap Kinerja Perekonomian Provinsi di Indonesia: Kebijakan Ekonomi dan Keuangan. 18(3): 197 - 208

Calderon C, Luis Sn. 204. The Effects of Infrastructure Development on Growth and Income Distribution. World Bank Policy Research Working Paper, 3400.

Desai RM, Freinkman LM, Goldberg I. 2003. Fiscal Federalism and Regional Growth: Evidence from the Russian Federation in the 1990s. World Bank Policy Research, Working Paper 3138.

Fan S. 2002. Growth, Inequality, and Poverty in Rural China, The Role of Public Investment. International Food Policy Research Institute. Washington DC

Iimi A. 2005. Decentralization and Economic Growth Revisited: An Empirical Note. Journal of Urban Economic, 57: 449-460.

Ismail AG, Hamzah MZ, Ritonga JT. 2004. Fiscal Decentralization and Economic Growth: Evidence From Selected Muslim Countries.
Jurnal Ekonomi Pembangunan, 9(2):109-11

Kuznets S. 1955. Economic Growth and Income Inequality. The American Economic Review, 45(1): 1-28.

Lisna 2014. Dampak kapasitas Fiskal terhadap Perekonomian dan Kemiskinan Sektoral Daerah di Indonesia: Suatu Analisis Simulasi Kebijakan. [Disertasi]. Sekolah Pascasarjana Institut Pertanian Bogor: Bogor

Nanga M. 2006. Dampak Transfer Fiskal Terhadap Kemiskinan Di Indonesia : Suatu Analisis Simulasi Kebijakan. [Disertasi]. Sekolah Pascasarjana Institut Pertanian Bogor

Muslianti D. 2011. Dampak kebijakan fiskal daerah terhadap Kemiskinan di indonesia Pada masa desentralisasi fiskal. Tesis. Sekolah pascasarjana Institut pertanian bogor Bogor

Prasetyo RB. 2009. Pengaruh Infrastruktur Pada Pertumbuhan Ekonomi Wilayah Di Indonesia: Jurnal Ekonomi dan Kebijakan Pembangunan. 2(2):222-236

Priyarsono. 2014. Beberapa Masalahdan Kebijakan Publik Tentang Infrastruktur: Tinjauan Dari Perspektif Ilmu Ekonomi. Orasi Ilmiah Guru Besar IPB. Bogor: IPB Press.

Ravallion M. 2006. Poverty Lines in Theory and Practice : Living Standards Measurement Study, World Bank : Working Paper No. 13, 1998.

Ray D. 1998. Development Economics. New Jersey: Princeton University Press

Siregar H, Wahyuniarti D. 2007. Dampak Pertumbuhan Ekonomi terhadap Penurunan Jumlah Penduduk Miskin. IPB dan Brighten Institute. 
Sumedi. 2013. Dampak pengeluaran pemerintah terhadap Perekonomian daerah dan kemiskinan dalam Kerangka desentralisasi fiskal. [Disertasi]. Sekolah Pascasarjana Institut Pertanian Bogor: Bogor

Sutarsono. 2012. Hubungan tata kelola pemerintahan, Infrastruktur dan pertumbuhan ekonomi Di indonesia. [Tesis]. Sekolah Pascasarjana Institut Pertanian Bogor: Bogor
Todaro MP, Smith SC. 2006. Pembangunan Ekonomi. Edisi Kesembilan. Jakarta: Erlangga.

World Bank.2000. World Development Report 2006. Oxford University Press, Oxford.

Yudhoyono SB. 2004. Pembangunan Pertanian dan Pedesaan Sebagai Upaya Mengatasi Kemiskinan dan Pengangguran: Analisis EkonomiPolitik Kebijakan Fiskal. Disertasi Doktor. Sekolah Pascasarjana, Institut Pertanian Bogor, Bogor. 